Af Lotte Thing Rasmussen,

ltr@bib.sdu.dk

Videndeling i store organisationer er en svær størrelse. På Syddansk Universitetsbibliotek fungerer konceptet Frokosttalks på femte år som en samlepakke af intern kompetenceudvikling, videndeling og social lim.

\title{
Fem år med frokostsnak
}

Super-piger: køn, magt og diversitet, Fantastic robots and where to find them og Bibliotekets skjulte Kinderæg er eksempler på Frokosttalk-titler, som siden 2017 har været afholdt regelmæssigt på Syddansk Universitetsbibliotek (SDUB).

En Frokosttalk består af et oplæg på ca. 20 minutter af en medarbejder eller chef fra biblioteket med mulighed for spørgsmål og debat de sidste 10 minutter. Nogle gange inviteres en ph.d.-studerende til at holde oplæg, hvilket både er inspirerende, men også en måde at holde sig ajour med nogle af de forskningsprojekter, der pågår i fagmiljøerne.

Bibliotekets Frokosttalks giver inspiration, videndeling og orientering i en stor organisation med meget forskelligartede arbejdsopgaver, hvor det kan være svært at følge med i alt det, der foregår. Det er ikke en officiel kanal, vi informerer via, men et rum for uformel videndeling, og det er et rigtig godt supplement.
- Det giver os også noget på den sociale konto, siger afdelingsleder for Informationssektionen Jens Dam, som er ledelsesmæssigt ansvarlig for Frokosttalks.

Konceptet er initieret og drevet af bibliotekar Britta Toftgaard Holton, som, i lighed med Jens Dam, mener, at det er vigtigt, det er medarbejderdrevet.

- Folk kan tillade sig at sige nej til mig, når jeg spørger, om de vil stå for en Frokosttalk. Og det har en betydning, for det skal ikke være et koncept, der stresser, men tværtimod helst noget, der giver et eller andet ekstra, siger Britta Toftgaard Holton.

\section{Feedback}

Og det lader til at være lykkedes. For det seneste initiativ fra Britta Toftgaard Holton er en mindre spørgeskemaundersøgelse blandt kollegaerne om, hvad de synes om Frokosttalks. Blandt de 33 besvarelser, med respondenter fra campusbibliotekerne i både Sønderborg, Slagelse, Esbjerg, Kolding og Odense, er der generelt en meget positiv holdning.
Til spørgsmålet Føler du, at arrangementet bidrager med noget til dit daglige arbejde? er der en del uddybende kommentarer, blandt andet at Frokosttalks bidrager til at formidle viden på tværs af bibliotekets afdelinger, giver nem og overskuelig orientering fra andre afdelinger og kollegaer, noget ekstra socialt, at vi lærer hinanden lidt bedre at kende, at det giver inspiration og er godt med emner, der ikke nødvendigvis er tæt på den enkeltes arbejdsopgaver, så indsigten i organisationen øges, sparring og feedback fremhæves og sågar øget trivsel er nævnt.

\section{Konceptet}

Den første Frokosttalk på biblioteket blev afholdt i efteråret 2017 af forskningsbibliotekar Katrine Astrup Jacobsen, som gav et klassisk tips-og-tricks oplæg til databasen Engineering Village. Konceptet gik i første omgang kun ud til campus Odense og blev præsenteret som "Et lille efterårsforsøg, som afprøves i de kommende måneder her på Campus Odense. 



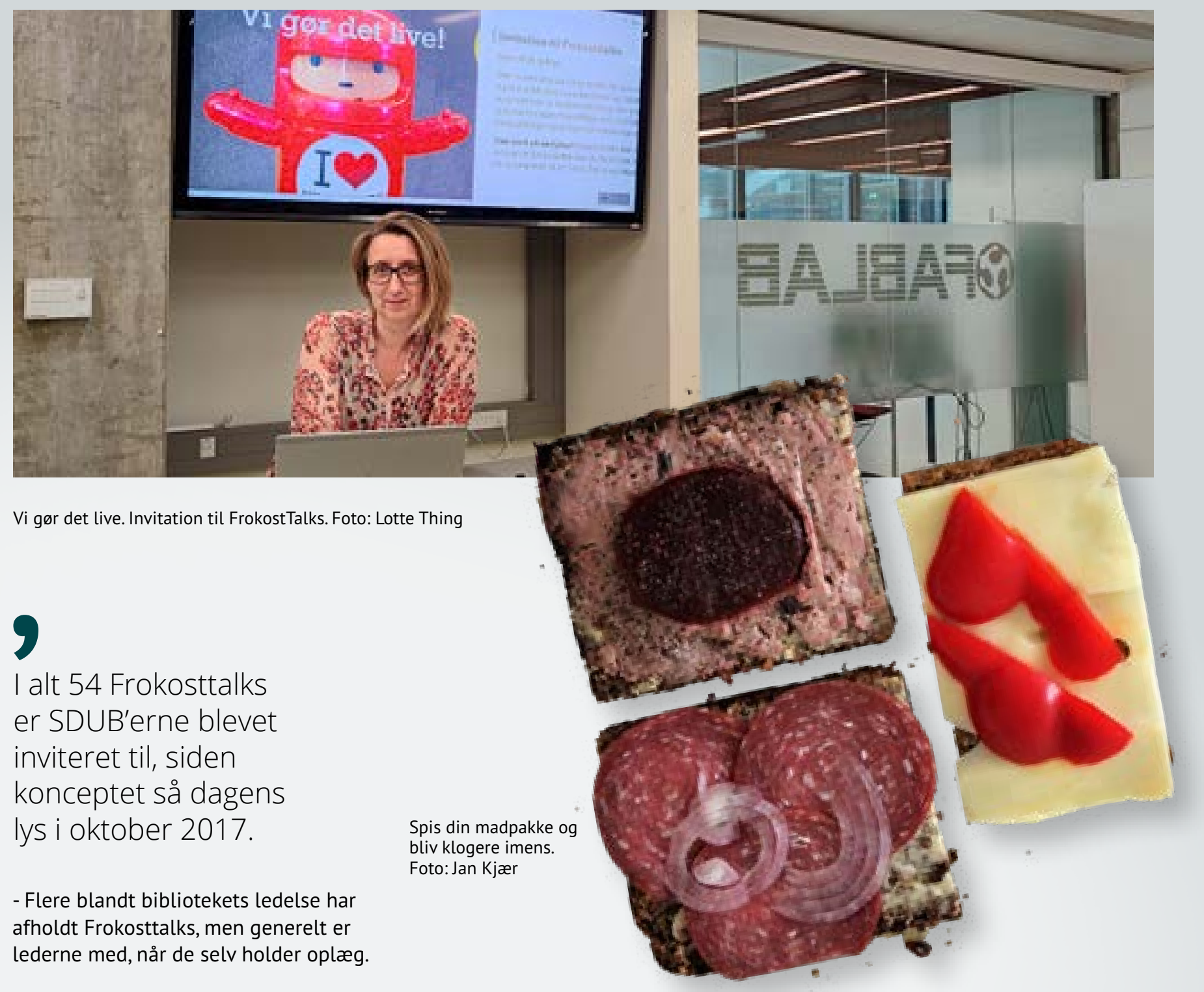

- I ledelsen er vi meget opmærksomme på at informere og formidle via de formelle kanaler. Der kunne godt være en ide $i$, at vi i højere grad husker denne kanal, også som deltagere. Det vil jeg gerne tage med til de øvrige ledere. Jeg bestræber mig altid selv på at deltage og lytte med, hvis jeg ikke har andet i kalenderen, siger Jens Dam.

Jens Dam har selv stået for flere talks, ligesom både bibliotekschef Bertil Dorch og Souschef Thomas Kaarsted har optrådt ved flere lejligheder.

Lotte Thing Rasmussen er specialkonsulent og journalist ved Syddansk Universitetsbibliotek.

\section{Frokosttalks bliver til BIBTalks}

I alt 54 Frokosttalks er SDUB'erne blevet inviteret til, siden konceptet så dagens lys i oktober 2017.

2021 har været et stort år for Frokosttalks, hvor 19 talks er afholdt, inklusiv de planlagte i november og december, kun overgået af 2018 , hvor året bød på 20 Frokosttalks.

På foranledning af undersøgelsen blandt medarbejderne justerer Britta og Jens nu i konceptet, så det fremover hedder BIBTalks og ligger om formiddagen eller eftermiddagen.

Corona var sparket til at gøre Frokosttalks online med den fordel, at alle campusbyer kan deltage på lige fod. Der eksperimenteres fortsat med, om konceptet skal være online eller blended. 